\title{
Pendidikan Kesehatan Sebagai Upaya Peningkatan Pengetahuan Kesehatan dan Penyakit Sistem Perkemihan Selama Kehamilan
}

\author{
${ }^{1}$ Rita Dwi Hartanti*, ${ }^{2}$ Emi Nurlaela \\ ${ }^{1,2}$ Program Studi Sarjana Keperawatan dan Pendidikan Profesi Ners, Fakultas Ilmu Kesehatan, \\ Universitas Muhammadiyah Pekajangan Pekalongan \\ *Penulis korespondensi, email: ritadwihartanti85@gmail.com
}

(Received: 3 April 2021 /Accepted: 25 July 2021/Published: 31 July 2021)

\begin{abstract}
Abstrak
Perubahan fisiologis pada sistem perkemihan selama kehamilan seperti peningkatan frekuensi berkemih, tertahannya air kencing pada kandung kemih dan tertekannya kandung kemih akibat membesarnya rahim dapat menimbulkan berbagai keluhan pada ibu hamil. Selama masa kehamilan, selain kesehatan reproduksi dan kesehatan janin, ibu hamil harus tetap memperhatikan kesehatan tubuh yang lain seperti kesehatan sistem perkemihan. Kurangnya pengetahuan dan kurangnya informasi ibu hamil tentang kesehatan perkemihan khususnya pada masa kehamilan, menjadikan ibu hamil beresiko mengalami gangguan / penyakit pada sistem perkemihan. Ibu hamil di wilayah kerja Puskesmas Kedungwuni I Pekalongan belum pernah mendapatkan pendidikan tentang kesehatan dan penyakit sistem perkemihan selama kehamilan. Untuk mengatasi permasalahan tersebut makan penulis melakukan pengabdian masyarakat pendidikan kesehatan sebagai upaya peningkatan pengetahuan tentang kesehatan dan penyakit sistem perkemihan selama kehamilan pada ibu hamil di wilayah kerja Puskesmas Kedungwuni I. Kegiatan yang telah dilakukan adalah pendidikan kesehatan yang diberikan kepada ibu hamil di wilayah puskesmas Kedungwuni I yang meliputi tiga desa yaitu Desa Kedungwuni Timur, Desa Podo dan Desa Salakbrojo. Kegiatan ini dihadiri oleh ibu hamil baik ibu hamil trisemester I, II dan III yang berjumlah 109 ibu hamil. Hasil evaluasi dari kegiatan ini adalah meningkatnya pengetahuan ibu hamil tentang berbagai penyakit sistem perkemihan yang dapat terjadi pada ibu hamil selama masa kehamilan dan cara pencegahan serta penatalaksanaan jika terjadi penyakit yang berhubungan dengan sistem perkemihan selama kehamilan. Dibuktikan setelah dilakukan pengambilan data pengetahuan ibu hamil tentang kesehatan system perkemihan menunjukkan peningkatan pengetahuan yaitu sebanyak 90\% ibu hamil di Desa Salak Brojo, 100\% di Desa podo dan 96,3\% di desa kedungwuni Timur.
\end{abstract}

Kata Kunci : Pendidikan Kesehatan, Peningkatan pengetahuan; Pengetahuan Kesehatan; Penyakit Sistem Perkemihan; Ibu Hamil.

\begin{abstract}
Physiological changes in the urinary system during pregnancy such as increasing urination frequency, retention of urine in the bladder, and pressure on the bladder due to the enlargement of the uterus can cause various complaints to pregnant women. During pregnancy, pregnant women must pay attention to not only reproductive and fetal health, but also the health other body parts, such as the urinary system. Lack of knowledge and information for pregnant women about urinary health, especially during pregnancy, puts pregnant women at risk of experiencing disorders or diseases of the urinary system. Pregnant women in the working area of Puskesmas Kedungwuni I had never received education about urinary system health and diseases during pregnancy. To overcome this problem, the authors carried out a community service namely health education as an effort to increase knowledge about health and urinary system diseases during
\end{abstract}


pregnancy to pregnant women in the working area of Puskesmas Kedungwuni I. Activities that had been carried out were health education provided to pregnant women in the area of Puskesmas Kedungwuni I including three villages: Kedungwuni Timur, Podo, and Salakbrojo. This activity was attended by 109 pregnant women of the first, second and third trimesters. The result of this activity was the increased knowledge of pregnant women about various urinary system diseases that can be experienced by pregnant women as well as how to prevent and manage diseases related to the urinary system during pregnancy. It was proven by the collected data showing that knowledge of pregnant women about the health of the urinary system increased as much as 90\% in Desa Salak Brojo, 100\% in Desa Podo and 96.3\% in Desa Kedungwuni Timur.

Keywords : Health Education, Increased knowledge; Health Knowledge; Urinary System Diseases; Pregnant mother

\section{Pendahuluan}

Kesehatan selama kehamilan merupakan salah satu kesehatan yang menjadi perhatian penting. Kesehatan selama kehamilan yang baik akan meningkatkan kualitas generasi berikutnya. Salah satu kesehatan yang perlu diperhatikan selama kehamilan adalah kesehatan pada area sistem perkemihan. Kesehatan pada area sistem perkemihan perlu diperhatikan karena selama kehamilan juga terjadi perubahan fisiologis yang juga dapat mempengaruhi keadaaan atau kesehatan pada sistem perkemihan (Dinç, 2018).

Berbagai perubahan fisiologis sistem perkemihan selama kehamilan diantaranya peningkatan frekuensi berkemih, terutama pada semester pertama dan ketiga, peningkatan produksi cairan vagina, tertahannya air kencing pada kandung kemih dapat meningkatkan resiko mengalami penyakit pada sistem perkemihan selama kehamilan. Penyakit pada sistem perkemihan yang sering terjadi selama kehamilan adalah infeksi saluran kemih (Chabibah \& Khanifah, 2019).

Gangguan atau infeksi sistem perkemihan menjadi salah satu penyakit yang sering terjadi selama kehamilan, salah satu penyebabnya adalah retensi urin yang terjadi pada masa kehamilan khususnya pada trisemester I dan III. Penyebab lain diantaranya adalah kebiasaan ibu hamil untuk menahan air kencing, buang air kecil tidak tuntas dan akibat kebiasaan ibu kurang tepat dalam membersihkan area genital pada masa kehamilan. Tingginya angka infeksi saluran kemih selama kehamilan menjadi perhatian penting. Insiden infeksi saluran kemih selama kehamilan semakin meningkat seiring bertambahnya usia kehamilan. 58\% kejadian infeksi saluran kemih meningkat selama kehamilan, terutama setelah kehamilan 30 minggu (Nurlaela \& Hartanti, 2020).

Puskesmas Kedungwuni I yang merupakan unit pelayanan dasar kesehatan masyarakat memiliki peran sebagai instansi kesehatan dasar pertama. Puskesmas kedungwuni I merupakan salah satu puskesmas yang berada di wilayah kabupaten Pekalongan, dengan cakupan wilayah terdapat 11 desa. Puskesmas kedungwuni I merupakan Puskesmas di wilayah Kabupaten Pekalongan yang memiliki jumlah ibu hamil terbesar ketiga di wilayah Kabupaten Pekalongan. Setiap desa di wilayah kerja Puskesmas Kedungwuni 1 sudah memiliki perawat desa dan bidan desa sebagai penanggung jawab kesehatan di masing-masing desa. Namun pemberian informasi kesehatan dasar belum semua disampaikan oleh perawat atau bidan desa sehingga masih banyak informasi kesehatan yang perlu diberikan kepada masyarakat terutama ibu hamil karena jumlah ibu hamil yang ada di wilayah puskesmas kedungwuni I terbanyak ketiga di Kabupaten Pekalongan. Informasi-informasi tentang kesehatan ibu hamil hanya diberikan saat kegiatan posyandu dan saat ibu hamil periksa ke Puskesmas. Berdasarkan wawancara dengan bidan koordinator Puskesmas, perawat desa dan bidan desa wilayah Puskesmas Kedungwuni I didapatkan data bahwa Ibu hamil di wilayah kerja puskesmas kedungwuni belum pernah mendapatkan informasi dan pendidikan kesehatan tentang berbagai penyakit pada sistem perkemihan yang dapat terjadi selama kehamilan. 
Kegiatan pengabdian masyarakat dengan memberikan pendidikan kesehatan tentang kesehatan dan penyakit sistem perkemihan, perlu dilakukan dan diberikan kepada ibu hamil untuk meningkatkan pengetahuan dan kemampuan ibu hamil dalam menjaga kesehatan sistem perkemihan selama masa kehamilan. Kegiatan pengabdian masyarakat ini bertujuan untuk meningkatkan pengetahuan ibu hamil dalam mengenali penyakit - penyakit pada sistem perkemihan yang bisa terjadi selama masa kehamilan, mengingat kesehatan sistem perkemihan erat kaitannya dengan kesehatan reproduksi terutama di masa kehamilan. Selain tujuan yang telah disebutkan sebelumnya, pendidikan kesehatan yang diberikan bertujuan juga untuk meningkatkan kemampuan ibu hamil untuk menjaga kesehatan sistem perkemihan di masa - masa kehamilan.

\section{Metode}

Kegiatan ini merupakan kegiatan pengabdian kepada masyarakat yang dilakukan sebagai salah satu tridharma perguruan tinggi yang dilakukan oleh penulis. Kegiatan ini dilakukan sebagai salah satu upaya meningkatkan pengetahuan masyarakat tentang kesehatan khususnya kesehatan sistem perkemihan dan penyakit yang dapat terjadi selama masa kehamian. Pendekatan yang digunakan dalam kegiatan ini adalah Komunikasi Informasi dan Edukasi (KIE) melalui kegiatan pendidikan kesehatan kepada masyarakat dengan sasaran kegiatan adalah ibu hamil.

Metodologi pelaksanaan kegiatan pengabdian masyarakat yang telah dilakukan meliputi:

\section{a. Tahap persiapan}

Tahap persiapan dilakukan selama kurang lebih tiga minggu, dengan rangkaian tahap persiapan yang dilakukan meliputi kegiatan :

1) Pembuatan proposal dan rencana kegiatan serta pengajuan proposal kepada LPPM Universitas Muhammadiyah Pekajangan Pekalongan.

2) Mengurus perijinan kegiatan ke BAPEDA dan Dinas kesehatan Kabupaten Pekalongan dan kepada Kepala Puskesmas Kedungwuni I

3) Melakukan koordinasi dengan perawat desa, bidan desa dan kader kesehatan untuk dapat mendata dan mengumpulkan ibu hamil yang akan mengikuti kegiatan pengabdian masyarakat ini serta perangkat desa di setiap desa yang akan menjadi tempat kegiatan..

\section{b. Tahap pelaksanaan kegiatan}

Pelaksanaan kegiatan pengabdian masyarakat dilaksanakan selama satu bulan yaitu pada bulan Januari 2019. Kegiatan yang dilakukan adalah melakukan pemeriksaan kesehatan umum ibu hamil dan memberikan pendidikan kesehatan tentang kesehatan sistem perkemihan dan penyakit pada sistem perkemihan selama kehamilan. Kegiatan ini dilakukan di tiga desa wilayah kerja Puskesmas Kedungwuni. Desa yang terpilih sebagai tempat kegiatan merupakan desa dengan jumlah ibu hamil terbanyak yang belum pernah dilakukan pendidikan kesehatan tentang penyakit pada sistem perkemihan selama kehamilan. Selain kriteria tersebut desa yang terpilih adalah desa yang pelaksanaan kelas hamilnya belum rutin diadakan. Desa yang terpilih pada kegiatan pengabdian masyarakat ini adalah desa Kedungwuni Timur, Desa Podo dan Desa Salakbrojo. Desa Kedungwuni Timur memiliki ibu hamil sebanyak 54 ibu hamil, desa Podo memiliki jumlah ibu hamil sebanyak 17 ibu hamil dan desa Salakbrojo memiliki 43 ibu hamil.

Rangkaian kegiatan yang dilakukan pada pengabdian masyarakat "Pendidikan Kesehatan Sebagai Upaya Peningkatan Pengetahuan Tentang Kesehatan dan Penyakit Pada Sistem Perkemihan Selama Kehamilan meliputi :

\section{1) Pemeriksaan Umum Ibu Hamil}


Pemeriksaan umum ibu hamil dalam kegiatan ini dilakukan sebelum kegiatan pendidikan kesehatan diberikan. Pemeriksaan yang dilakukan meliputi pemeriksaan tanda vital (pengukuran tekanan darah, pengukuran nadi, pengukuran frekuensi pernapasan dan pengukuran suhu), pemeriksaan terhadap keluhan seputar gangguan sistem perkemihan (keluhan berkemih, ketidakmampuan mengosongkan kandung kemih dan sensasi tidak nyaman saat berkemih). Adapun kegiatan pemeriksaan umum pad aibu hamil terkait system perkemihan ditunjukkan pada gambar 1 sebagai berikut

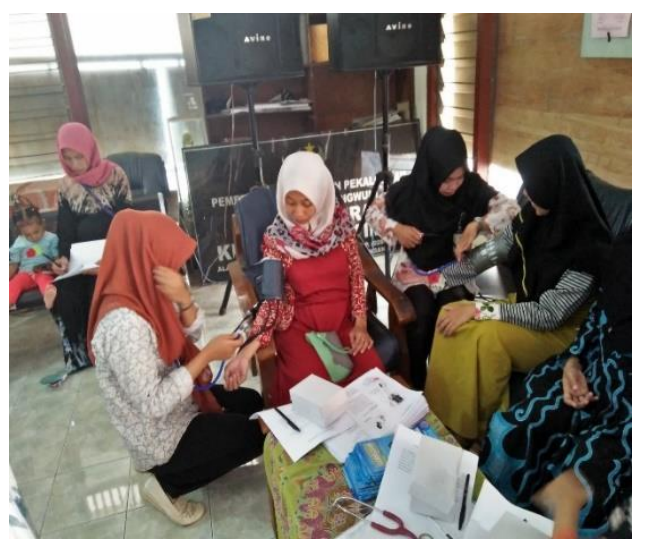

Gambar 1. Kegiatan Pemeriksaan Ibu Hamil

2) Pendidikan Kesehatan Tentang Kesehatan Sistem Perkemihan dan Penyakit Yang Dapat Terjadi Pada Sistem Perkemihan selama kehamilan

Kegiatan pendidikan kesehatan yang diberikan dilakukan sesuai dengan tujuan. Rangkaian kegiatan meliputi : pembukaan, persamaan persepsi, pengambilan data pengetahuan ibu hamil tentang kesehatan sistem perkemihan, penyampaian tujuan kegiatan, penyampaian materi, diskusi dan tanya jawab, evaluasi kegiatan pendidikan kesehatan, pengambilan data pengetahuan ibu hamil tentang kesehatan system perkemihan dan penutup. Materi yang disampaikan dalam kegiatan pengabdian masyarakat ini adalah materi tentang kesehatan sistem perkemihan selama kehamilan, yang disampaikan oleh ibu Emi Nurlaela, M.Kep.,Sp.Mat, dilanjutkan dengan materi kedua yaitu tentang penyakit sistem perkemihan yang dapat terjadi pada masa Kehamilan dan cara mencegah penyakit sistem perkemihan selama masa kehamilan. Pelaksanaan kegiatan pengabdian masyarakat ini dilakukan secara bergantian sesuai dengan kontrak waktu yang ditetapkan bersama penulis, bidan desa, kader kesehatan dan ibu hamil di desa Kedungwuni Timur, Desa Podo dan Desa Salakbrojo. Dalam kegiatan ini juga dilakukan pengambilan data pengetahuan ibu hamil tentang kesehatan system perkemihan selama masa kehamilan yang dilakukan pada saat sebelum dan sesudah kegiatan Pendidikan kesehatan. Instrument yang digunakan dalam pengambilan data pengetahuan ibu hamil tentang kesehatan sistem perkemihan dengan menggunakan kuesioner pengetahuan ibu hamil tentang sistem perkemihan yang penulis gunakan dalam penelitian tentang gambaran pengetahuan ibu hamil tentang sistem perkemihan pada tahun 2019. Adapun kegiatan pendidikan kesehatan yang dilakukan ditujukkan pada gambar 2 berikut ini: 

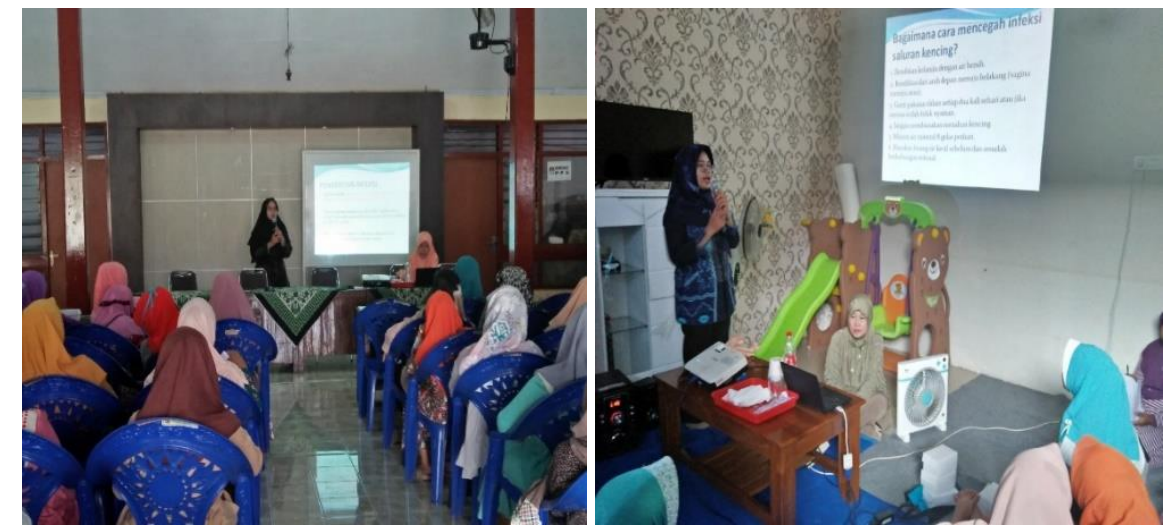

Gambar 2. Kegiatan Pendidikan Kesehatan Tentang Kesehatan Sistem Perkemihan

\section{c. Tahap Evaluasi Kegiatan}

Evaluasi kegiatan pengabdian masyarakat ini, dilakukan pada saat proses pendidikan kesehatan berlangsung dan saat akhir dari kegiatan pendidikan kesehatan. Evaluasi kegiatan dilakukan dengan memberikan pertanyaan dan reinforcement positif kepada peserta ibu hamil yang menjawab pertanyaan pembicara dan memberikan pertanyaan. Evaluasi pertanyaan dilakukan dengan memberikan pertanyaan tentang kesehatan perkemihan, pentingnya menjaga kesehatan sistem perkemihan dan penyakit yang sering terjadi pada sistem perkemihan selama kehamilan kepada ibu hamil yang menjadi subyek atau sasaran pada pengabdian masyarakat kali ini.

\section{d. Keberlanjutan Program}

Keberlanjutan program yang dilakukan adalah dengan melakukan pelaporan kegiatan kepada LPPM Universitas Muhammadiyah Pekajangan Pekalongan, perawat desa, bidan desa dan kepala Puskesmas Kedungwuni I, terkait kegiatan yang sudah dilaksanakan. Kemudian akan dilanjutkan dengan pelatihan pemeriksaan sistem perkemihan pada ibu hamil untuk perawat desa dan bidan desa. Selanjutnya, pemeriksaan kesehatan system perkemihan pada ibu hamil akan dilakukan oleh perawat desa dan bidan desa dalam bentuk kegiatan pendidikan kesehatan secara berkala dan pengadaan kelas kehamilan oleh bidan desa.

\section{Hasil dan Pembahasan}

Pendidikan kesehatan dilakukan di tiga tempat atau tiga desa di wilayah kerja puskesmas kedungwuni I Kabupaten Pekalongan, yaitu di desa Podo, Desa Salah Brojo dan Desa Kedungwuni Timur. Kegiatan ini dihadiri oleh ibu hamil di ketiga desa tersebut. Kegiatan penyuluhan kesehatan yang dilakukan di balai desa Salak Brojo dengan diikuti oleh 43 ibu hamil dan 3 kader pembina kesehatan. Kegiatan pengabdian masyarakat di desa Salak Brojo dilakukan pada hari sabtu 12 Januari 2019. Kegiatan berjalan lancar dan ibu hamil terlihat memperhatikan dan antusias bertanya tentang materi yang disampaikan. Hasil evaluasi pelaksanaan kegiatan pengabdian masyarakat tersebut berjalan lancar dan terdapat peningkatan pengetahuan ibu hamil tentang kesehatan sistem perkemihan. Hal ini terlihat dari kemampuan ibu menjawab dan mengambil keputusan dalam melakukan cara perawatan area genital dan area sistem perkemihan terutama selama masa kehamilan.

Kegiatan pengabdian masyarakat yang kedua dilaksanakan di Desa Podo. Kegiatan dilaksanakan di rumah bidan desa Podo yang diikuti oleh 17 ibu hamil. Kegiatan dilakukan sebagai salah satu kegiatan dalam kelas ibu hamil. Kegiatan dilaksanakan pada hari kamis, 17 Januari 2019. Kegiatan berlangsung tertib. Ibu hamil merasa lebih tahu setelah dilakukan penyuluhan dan merasa senang sudah dilakukan kegiatan tersebut. Hal ini dikarenakan biasanya informasi yang didapatkan adalah informasi tentang kehamilan dan perawatan 
kehamilan sedangkan saat kegiatan informasi yang didapatkan lebih karena bukan hanya kehamilan saja namun juga informasi tentang kesehatan sistem perkemihan.

Kegiatan ketiga dari pengabdian masyarakat ini dilaksanakan di Desa Kedungwuni Timur. Kegiatan dilaksanakan di balai desa Kedungwuni Timur dan diikuti oleh 54 ibu hamil yang berada di wilayah kerja Puskesmas Kedungwuni 1 khususnya desa Kedungwuni Timur. Kegiatan berjalan baik, ibu hamil terlihat antusias dan gembira karena informasi yang diberikan sangat mereka butuhkan karena selama ini mereka merasa tidak tahu tentang menjaga kesehatan sistem perkemihan selama kehamilan. Mereka hanya melakukan kebiasaan saja seperti yang dikatakan orang tua selama hamil. Berdasarkan wawancara dengan ibu hamil, dengan kegiatan penyuluhan ini ibu hamil menjadi lebih bisa memperhatikan dan menjaga kesehatan sistem perkemihan terutama saat hamil dan setelah melahirkan nanti.

Hasil yang didapatkan dalam kegiatan pendidikan kesehatan antara lain dapat dilihat pada tabel berikut ini :

Tabel 1. Gambaran Tingkat Pengetahuan Ibu Sebelum Dan Sesudah Dilakukan Pendidikan

Kesehatan Tentang Penyakit Sistem Perkemihan Selama Masa Kehamilan di Desa Salak Brojo Puskesmas Kedungwuni I Kabupaten Pekalongan Tahun $2019 \quad(\mathrm{n}=43)$

\begin{tabular}{ccc}
\hline Tingkat Pengetahuan Ibu Hamil & $\begin{array}{c}\text { Sebelum Pendidikan } \\
\text { Kesehatan }\end{array}$ & $\begin{array}{c}\text { Sesudah Pendidikan } \\
\text { Kesehatan }\end{array}$ \\
\hline Pengetahuan Kurang & $29(67 \%)$ & $5(10 \%)$ \\
Pengetahuan Baik & $14(33 \%)$ & $38(90 \%)$ \\
n & $43(100 \%)$ & $43(100 \%)$ \\
\hline
\end{tabular}

Berdasarkan Tabel 1. dapat diketahui bahwa terdapat peningkatan tingkat pengetahuan ibu hamil di Desa Salak Brojo sebelum diberikan pendidikan kesehatan dengan setelah diberikan pendidikan kesehatan. ibu yang memiliki pengetahuan baik sebelum kegiatan pendidikan kesehatan sebanyak 14 responden (33\%) menjadi 38 responden $(90 \%)$ setelah diberikan pendidikan kesehatan.

Tabel 2. Gambaran Tingkat Pengetahuan Ibu Sebelum Dan Sesudah Dilakukan Pendidikan

Kesehatan Tentang Penyakit Sistem Perkemihan Selama Masa Kehamilan di Desa Podo Puskesmas Kedungwuni I Kabupaten Pekalongan Tahun 2019 ( $\mathrm{n}=17$ )

\begin{tabular}{ccc}
\hline Tingkat Pengetahuan Ibu Hamil & $\begin{array}{c}\text { Sebelum Pendidikan } \\
\text { Kesehatan }\end{array}$ & $\begin{array}{c}\text { Sesudah Pendidikan } \\
\text { Kesehatan }\end{array}$ \\
\hline Pengetahuan Kurang & $13(76,5 \%)$ & $0(10 \%)$ \\
Pengetahuan Baik & $4(23,5 \%)$ & $17(100 \%)$ \\
$\mathrm{n}$ & $17(100 \%)$ & $17(100 \%)$ \\
\hline
\end{tabular}

Berdasarkan Tabel 2. dapat diketahui bahwa terdapat peningkatan tingkat pengetahuan ibu hamil di Desa Podo sebelum diberikan pendidikan kesehatan dengan setelah diberikan pendidikan kesehatan. ibu yang memiliki pengetahuan baik sebelum kegiatan pendidikan kesehatan sebanyak 4 responden $(23,5 \%)$ menjadi 17 responden $(100 \%)$ setelah diberikan pendidikan kesehatan.

Tabel 3. Gambaran Tingkat Pengetahuan Ibu Sebelum Dan Sesudah Dilakukan Pendidikan Kesehatan Tentang Penyakit Sistem Perkemihan Selama Masa Kehamilan di Desa

Kedungwuni Timur Puskesmas Kedungwuni I Kabupaten Pekalongan Tahun 2019 (n= 54)

\begin{tabular}{ccc}
\hline Tingkat Pengetahuan Ibu Hamil & $\begin{array}{c}\text { Sebelum Pendidikan } \\
\text { Kesehatan }\end{array}$ & $\begin{array}{c}\text { Sesudah Pendidikan } \\
\text { Kesehatan }\end{array}$ \\
\hline Pengetahuan Kurang & $39(72,3 \%)$ & $2(3,7 \%)$ \\
Pengetahuan Baik & $15(27,7 \%)$ & $52(96,3 \%)$ \\
n & $54(100 \%)$ & $54(100 \%)$ \\
\hline
\end{tabular}


Berdasarkan Tabel 3. dapat diketahui bahwa terdapat peningkatan tingkat pengetahuan ibu hamil di Desa Kedungwuni Timur sebelum diberikan pendidikan kesehatan dengan setelah diberikan pendidikan kesehatan. ibu yang memiliki pengetahuan baik sebelum kegiatan pendidikan kesehatan sebanyak 15 responden $(27,7 \%)$ menjadi 52 responden $(96,3$ $\%)$ setelah diberikan pendidikan kesehatan.

Kesehatan sistem perkemihan selama kehamilan menjadi salah satu bagian yang penting dalam kesehatan ibu hamil. Selama masa kehamilan, akibat perubahan anatomi maupun fisiologi sistem perkemihan yang disebabkan oleh peningkatan kadar hormon progesteron dan obstruksi saluran kemih akibat pembesaran uterus, dilatasi ureter serta penurunan peristaltik ureter dapat meningkatkan resiko infeksi pada saluran kemih selama masa kehamilan. Peningkatan kadar hormone progesterone dan adanya obstruksi saluran kemih akibat pembesaran uterus pada ibu hamil, akan mengakibatkan dilatasi ureter. Obtruksi pada saluran kemih ibu hamil ini akan menyebabkan akumulasi urin yang dapat menjadi media bagi pertumbuhan bakteri pada saluran kemih. Kondisi ini meningkatkan resiko terjadinya komplikasi abortus, bayi lahir prematur dan lahir dengan berat badan rendah, serta meningkatkan kesakitan dan kematian ibu dan janin (Agung et al., 2018).

Kesehatan sistem perkemihan selama masa kehamilan, memiliki hubungan langsung dengan kesehatan reproduksi selama masa kehamilan. Perubahan anatomi dan fisiologi pada ibu hamil yang juga mengakibatkan perubahan anatomi pada system perkemihan, dimana pembesaran uterus pada ibu hamil terutama pada ibu hamil Trisemester ke III akan mengakibatkan obstruksi pada saluran kemih. Hal ini mengakibatkan tertahannya urin didalam kandung kemih dalam waktu yang lama, sehingga ibu hamil memiliki resiko tinggi untuk terjadinya infeksi saluran kemih (ISK) (Agung et al., 2018).

Pengetahuan kesehatan system perkemihan perlu ibu hamil miliki agar dapat mencapai kesehatan yang baik selama kehamilannya. Pengetahuan yang kurang akan kesehatan system perkemihan akan berpengaruh pada penurunan kondisi kesehatan ibu dan janin yang dikandungnya. Peningkatan pengetahuan ibu hamil tentang kesehatan dan penyakit sistem perkemihan selama kehamilan merupakan salah satu upaya preventif dan promotif dalam peningkatan kesehatan ibu hamil khususnya kesehatan pada area sistem perkemihan. Upaya yang dilakukan untuk meningkatkan pengetahuan ibu tentang kesehatan sistem perkemihan adalah dengan memberikan pendidikan kesehatan tentang kesehatan dan penyakit sistem perkemihan yang dapat terjadi selama masa kehamilan dan melakukan pemeriksaan kesehatan yang berhubungan dengan system perkemihan (Nurlaela \& Hartanti, 2020)

Hasil pengambilan data tingkat pengetahuan ibu hamil tentang penyakit pada system perkemihan selama kehamilan setelah dilakukan pengambilan data pengetahuan ibu hamil tentang kesehatan system perkemihan menunjukkan peningkatan pengetahuan yaitu sebanyak 90\% ibu hamil di Desa Salak Brojo, 100\% di Desa podo dan 96,3\% di desa kedungwuni Timur. Hal ini menunjukkan pentingnya Pendidikan kesehatan untuk meningkatkan pengetahuan ibu hamil tentang kesehatan system perkemihan selama masa kehamilan. Pendidikan kesehatan pada hakekatnya merupakan kegiatan penyampaian pesan khususnya pesan kesehatan baik kepada individu, kelompok maupun masyarakat (Astuti, Esthi Widi, \& Sulastri, 2012).

Pendidikan kesehatan juga memiliki peran penting dalam menunjang program kesehatan dan dapat menghasilkan perubahan atau peningkatan pengetahuan masyarakat dalam hal ini adalah ibu hamil. Perubahan pengetahuan akan berpengaruh terhadap perilaku kesehatan yang selanjutnya akan meningkatkan indikator kesehatan masyarakat (Nur et al., 2018). Pendidikan kesehatan dapat meningkatkan derajat kesehatan dan kesejahteraan, menurunkan ketergantungan dan meningkatkan derajat kesehatan seseorang. Peningkatan pengetahuan seseorang akan berdampak dalam perubahan sikap dan perilaku individu dalam menjaga kesehatan. Pendidikan kesehatan sebagai bagian dari promosi kesehatan diharapakan dapat menimbulkan dan membentuk kesadaran diri seseorang tentang pentingnya menjaga kesehatan dan memiliki perilaku yang baik dalam kesehatan (Hitatami et al., 2014). 


\section{Simpulan}

Pendidikan kesehatan merupakan salah satu upaya promotif dan preventif yang dapat dilakukan untuk meningkatkan pengetahuan seseorang yang berpengaruh terhdap perubahan perilaku seseorang. Perilaku yang baik terhadap kesehatan dapat menjadi salah satu indikator pencapaian kesehatan yang baik bagi individu, kelompok dan masyarakat yang akan berpengaruh juga pada derajat kesehatan suatu bangsa.

\section{Persantunan}

Ucapan terima kasih kami sampaikan kepada kepada Rektor dan Kepala Bidang Penelitian dan Pengabdian Masyarakat Universitas Muhammadiyah Pekajangan Pekalongan serta Dekan Fakultas Ilmu Kesehatan dan Ketua Program Studi Sarjana Keperawatan dan Pendidikan Profesi Ners Universitas Muhammadiyah Pekajangan Pekalongan yang telah memberikan dukungan moril dan materiil demi terlaksananya program pengabdian masyarakat ini. Ucapan terimakasih juga kami sampaikan kepada Kepala Puskesmas, Perawat Desa, Bidan Desa dan Kader kesehatan Puskesmas Kedungwuni I yang telah membantu dan menjadi mitra dalam pelaksanaan kegiatan pengabdian masyarakat ini.

\section{Referensi}

Agung, A., Nirmala, L., Dewi, C., Hana, W., Ayu, I., \& Arjani, S. (2018). Meditory. 6(4), 27-38.

Astuti, Esthi Widi, Sulastri, K. (2012). Pengaruh Pendidikan Kesehatan Terhadap Perubahan Pengetahuan dan Sikap Ibu Hamil dalam Mengkonsumsi Tablet Fe(Ferum) di Rumah Bersalin Sri Lumintu Surakarta. Skripsi, 1-15.

Chabibah, N., \& Khanifah, M. (2019). Layanan Kesehatan Ibu Hamil Berkseinambungan. GEMASSIKA: Jurnal Pengabdian Kepada Masyarakat, 3(1), 69. https://doi.org/10.30787/gemassika.v3i1.382

Dinç, A. (2018). Prevalence of Urinary Incontinence During Pregnancy and Associated Risk Factors. LUTS: Lower Urinary Tract Symptoms, 10(3), 303-307. https://doi.org/10.1111/luts.12182

Hitatami, E., Lestari, B., Susanto, H., Hilmanto, D., Dewi, T., \& Sunjaya, D. K. (2014). Pengaruh Pendidikan Kesehatan tentang Kehamilan Risiko Tinggi melalui Layanan Pesan Singkat terhadap Peningkatan Pengetahuan dan Sikap Ibu Hamil The Impact of Health Education Through Short Message Service Towards Knowledge and Attitude on Highrisk Pregna. Jurnal Pendidikan Dan Pelatihan Kebidanan Indonesia Universitas Padjadjaran, 1(21).

Nur, M. S. K., Khoiriyah, H. I., \& Kurniawan, D. (2018). Pengembangan Model Pendidikan Kesehatan Pada Ibu Hamil Untuk Menurunkan Angka Kematian Ibu Di Kabupaten Bogor. Pkm-P, 2(1), 23-30. https://doi.org/10.32832/pkm-p.v2i1.198

Nurlaela, E., \& Hartanti, R. D. (2020). Peningkatan Pengetahuan Ibu Hamil Mengenai Kesehatan Sistem Perkemihan Di Wilayah Kerja Puskesmas Kedungwuni I Kabupaten .... Proceeding of The URECOL, 473-479. http://repository.urecol.org/index.php/proceeding/article/view/1232 